\section{8. 体質の基準としての乳栚䗋穼の} 形態 後郎郎 川原 浩 (長大)

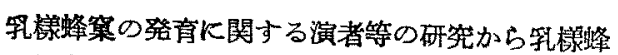

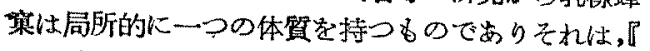

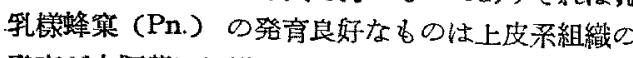

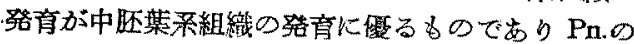
“発育不良なるのは中罘集条組織の発育が上皮系組瀻 の発育に優るもので安る日との考え炎抱くに至つた。

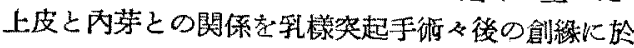
て組緇的に観察した結果の一部は川原力咋秋の九州

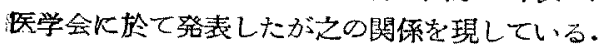

斯る局所的体筫が一般体啠と如何なる関係にある

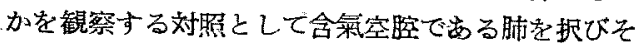

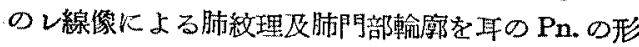
態と比較した：8才23例，14才16例，18才〜22才21 例，合計63例，8才の小胃はマントウ氏反応陰性のも のを択んだ，8才の小見てはPn. 良好なるの13例中 肺紋理微弱なすの9例，之に反しPn. 不良なるの10 例中肺秝理の强い, K本行与る.14才以上のるので同樣の関侯力゙諰め られるが前者程一致しない，更に炎庭刺战に対する

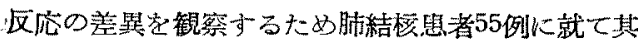

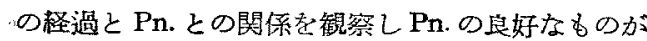
出性の変化老主とするとは限らないが Pn, の不良 なるのは増殖性の変化范主としていることは認めら れた.

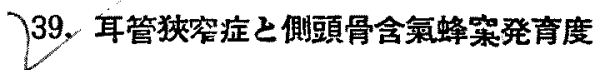

$$
\text { 片 桐 主一(弘前大) }
$$

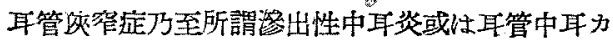

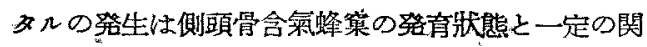
連性むる事が既に指摘されて来夫。余も亦最近弘前

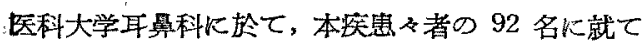
「レ」線捡盁を試みたのでその成鼣を報告する。便

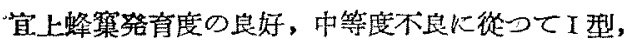
II型，III型に分類した・材料は满10才以上のものた 男性14名，女性48名，計92名で岕る。

1）思側別には右側 17 ，左側14，兩側61例で両側 政患力的多い。

2) 患耳総数 153 耳中I型 4 耳，II型22耳，III型 127 耳䀜型住83\%て極めて多い。

3) 左右両側の蜂策発育度老比較すると両側开型 70例で罠名多く (76\%) 两側I型, 11 例 (12\%) て
之に夷ぎ他位更に少い。

4) 両側蜂策登育度不等の6のでは発育良好側の みの罪患は見られなかつた。

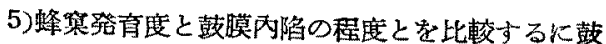
膜內陷高度のbのは而型にのみ見られ型工型に於 ては擜头內陷僌度のbのが多く見られた。

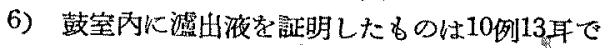
あるがすべて䗋窠発育度不良であつた。

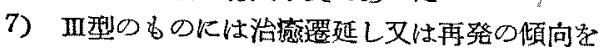
示寸すのが多い.

X

\section{0. 乳幼兒中耳炎の研究 其7. 慢性化膿性中耳炎飞就て}

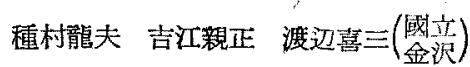

乳見に於ける慢性化膿性中耳炎は稀である。印ち 急性中耳炎100例に刘し慢性は1藏以下5.2,1歳6.90 岕るが，2歳となると 12.9 の比学示し以下年紫と共

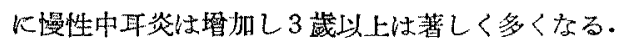

0 歲乃至 1 年 6 分位迄のるのは鼓膜に直径約 2 〜3 mm の円形の小登孔老るに過ぎなくて，大き

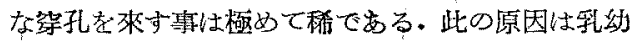
見の欧氏管の解剖的閶係化基因する。

漫性中耳资の分必液の細菌检楂の結果好急姓中耳 炎と䓔しく其趣党暴Kし，Staph. aureus, epidermidis, B. proteus Vulgaris, 及び B. pyocyaneus

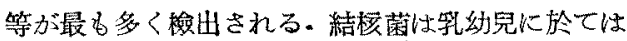
証明されなかつた. Typical E coli, Intermədialle

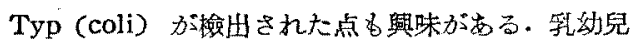
急性中耳炎の経過学锶察した应例に於て慢性化した b のは Staph. aureus, citreus, epidermidis 及び B. proteus vulgaris Kよるもので其他の起苂菌に よる急性中耳炎缊性化したるのがない。

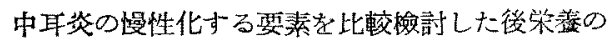
低下，個体の抵抗力の淢弱学來隹諸條件は慢性中耳 炎の成立に重要な因子であると共に,Staph. aureus citreus, epidermidis, B. proteus vulgaris 及び B. pyocyaneus 等吕慢性化に対しより雷裂な意義家 有するものと考へられる。

\section{1，近年に於ける急性中耳炎の 予後の変遷に就て}

田近露保 由中裕一(横浜医大) 